\title{
Role of Sodium Selenite in Ameliorating the Oxidative Stress of Gamma Radiation Exposure.
}

\author{
Hanafi N. \\ Radiation Biology Department, National Centre for Radiation Research and \\ Technology, Atomic Energy Authority, Cairo, Egypt
}

\begin{abstract}
Back ground: This work aims to investigate the role of Sodium Selenite $\left(\mathrm{NaSeO}_{3}\right)$ in ameliorating the oxidative stress of gamma radiation exposure. The relation between the antioxidant status, the histopahological changes and the immunohistological expression of p53 was evaluated.

Materials and methods: Adult male Swiss albino mice weighing 25-30g were used in this work. Lipid peroxidation and GSH activity levels were estimated in liver and intestinal tissues. Histopathological observations in addition to the immunohistological expression of p53 were also assayed. Experimental animals treated daily with $0.7 \mu \mathrm{g} / \mathrm{ml} / \mathrm{kg}$ body weight of $\mathrm{NaSeO}_{3}$ for two weeks. Some animals were exposed to $5 \mathrm{~Gy} \gamma$-irradiation and others exposed to $5 \mathrm{~Gy} \gamma$-irradiation and treated with $\mathrm{NaSeO}_{3}$.

Results: Due to ROS production, 5Gy $\gamma$-radiation induced a highly significant increase in lipid peroxidation and a significant decrease in GSH activity level in liver and intestine tissues. $\mathrm{NaSeO}_{3}$ supplementation revealed NS change in lipid peroxidation of liver and intestine tissues, while GSH levels recorded a significant increase as compared to the control group. Combined treatments with $\mathrm{NaSeO} 3$ supplementation and 5Gy $\gamma$-radiation revealed a significant amelioration in lipid peroxidation and GSH levels as compared to the irradiated groups. The histopathological observations went parallel to the biochemical records, while p53 expression was treatments and organs dependent.
\end{abstract}

Conclusion: $\mathrm{NaSeO}_{3}$ supplementation recorded ameliorated effects against cellular damage caused by radiation oxidative stress.

\section{Introduction}

Radiation is known to produce various reactive oxygen species (ROS) in biological systems such as superoxide, hydrogen peroxide and hydroxyl radical and various types of tissue damage due to free radical reactions (Adler et al., 1999). Reactive oxygen species (ROS) and free radicals induced by partial reduction of oxygen $\left(\mathrm{O}_{2}\right)$ react with cellular macromolecules (i.e., nucleic acids, lipids, proteins, and carbohydrates) (Sies, 1986) and induce their damage. In response to ionizing radiation induced DNA damage, cell cycle checkpoints and DNA repair are activated to protect the genome (Zhou and Elledge, 2000 ; Friedberg, 2003).The damage is properly repaired and the irradiated cells can resume proliferation or regenerate or develop tissues undergo apoptosis in response to ionizing radiation. p53 plays an essential role in ionizing radiation induced apoptosis.

p53 is a tumor-suppressor gene located on the short arm of chromosome 17 and has an important function in the regulation of the cell cycle and in promoting tumorigenesis (Okusa et al., 1996 ; Roviello et al., 1999). This gene encodes for the p53 protein, which increases the time necessary for DNA repair by slowing down the cell cycle at the G1-S transition, and suppresses tumor growth by causing apoptosis (Lanfrancone et al., 1994; Ryan et al., 2001). Alteration or inactivation of $p 53$ by mutation can allow a cell to escape from normal into 


\section{Hanafi N.}

uncontrolled growth leading to cancer development. p53 mutations are a very common genetic change in a variety of human tumors (Ryan et al., 2001; Starzynska et al., 1992). The wild-type p53 protein has a short half-life and is removed rapidly from the nucleus. On the contrary, mutant $p 53$ with a prolonged halflife accumulates in the nucleus, where it could be detected by immunohistochemistry. Therefore, the accumulation of the p53 protein may be considered an indicator of p53 gene mutation (Okusa et al., 1996; Starzynska et al., 1992).

The essential trace element selenium is of fundamental importance to human health. Its amount in vegetables and fruits is highly dependent on the soil content. As a constituent of selenoproteins, selenium has several structural and enzymatic roles; in the latter context it is best known as an antioxidant. Although investigation of selenium's role in health promotion has focused on its antioxidant activity (Holben and Smith ,1999), it has diverse biological functions, including the ability to suppress cell proliferation (Ganther ,1999), enhance immune response (KiremidjianSchumacher and Roy 1998), alter the metabolism of carcinogens (Ip ,1998), and induce apoptosis (Ganther ,1999). Providing selenium in its inorganic (e.g., selenite and selenate) or organic [e.g., selenocysteine and selenomethionine (Se Met)] forms has been found to meet nutritional needs. The biological activity of selenium actually reflects its expression in various compound forms (Ip, 1998). Kuchan and Milner (1992) provided rather compelling evidence that intracellular concentrations of glutathione were instrumental in determining the ability of selenite to alter cellular proliferation. In this study, we evaluated the immunohistochemical expression of p53 in liver and intestine tissues. The relationship between p53 expression, histopathologic features and the GSH and MDA levels as affected by $\gamma$ - radiation exposure and/ or Sodium selenite (selenium) consumption.

\section{Materials and methods}

\section{Animals}

Adult male Swiss albino mice weighing 25-30g were purchased from the breeding unit of the Egyptian Organization for Biological Products and Vaccines, Cairo and were used in this study. The animals were maintained on a commercial standard pellet diet and tap water ad libitum.

\section{Exposure of Animals to $\boldsymbol{\gamma}$-Radiation}

Mice were irradiated by whole body gamma irradiation using a Canadian ${ }^{137} \mathrm{Cs}$ Gamma Cell-40 at the National Centre for Radiation Research and Technology (NCRRT), Cairo, Egypt. The dose rate was $0.61 \mathrm{~Gy} / \mathrm{min}$.

\section{Sodium Selenite supplementation}

Sodium Selenite $\left(\mathrm{NaSeO}_{3}\right)$ was obtained from South Egypt Drug Industries Company (SEDCO) dissolved in distilled water at dose level $0.7 \mu \mathrm{g} / \mathrm{ml} / \mathrm{kg}$ body weight. $\mathrm{NaSeO}_{3}$ supplemented daily for two weeks.

\section{Groups under investigation.}

G1: Non irradiated non treated animals, served as control.

G2: Non irradiated and treated daily with $\mathrm{NaSeO}_{3}$ for two weeks.

G3: Whole body gamma irradiated mice with $5 \mathrm{~Gy}$.

G4: Animals treated with $\mathrm{NaSeO}_{3}$ before exposure to5Gy $\gamma$-irradiation.

Animals were sacrificed by cervical dislocation after one day of the last $\mathrm{NaSeO}_{3}$ and / or $\gamma$-irradiation treatment. Liver and the small intestine were dissected out for the present investigation.

\section{Biochemical analyses.}

For biochemical analyses small intestine and liver tissues were dissected out, and homogenized in ice cold phosphate buffer $(0.1 \mathrm{M} / \mathrm{pH} \quad 7.4)$ to give $10 \%$ homogenates for determination of reduced glutathione (GSH), and lipid peroxidation as malonadialdehyde (MAD). The level of Lipid peroxidation was ascertained by 
measuring malonadialdehyde level (MDA) content according to the method described by Ohkhawa et al. (1979). Glutathione (GSH) content was assayed calorimetrically according to the procedure of Moron et al. (1979).

\section{Histopathology.}

For histopathology samples of intestine and liver tissues were fixed in $10 \%$ formaldehyde. These samples were then dehydrated in ascending series of alcohol cleared in xylene and embedded in paraffin wax. Sections of $5 \mu \mathrm{m}$ thickness were cut and subsequently stained with Hx.\& E. dye.

\section{Immunohistochemistry.}

For immunohistochemistry, samples of intestine and liver tissues were fixed in 4\% formaldehyde in phosphate-buffered saline ( $\mathrm{pH}$ 7.4), before dehydration in alcohols and embedding in wax. Tissue sections were cut using a microtome at a thickness of $3 \mu \mathrm{m}$. Immunohistochemistry was performed using P53 Ab-1(clone PAb 240) mouse monoclonal antibody purchased from lab Vision Corporation. Immunohistochemistry was performed using anti mouse IgG $(\mathrm{H}+\mathrm{L})$ streptavidin peroxidase and diaminobenzidine as the immunodetection substrate.

In immunohistochemistry, slides were heated to $65^{\circ} \mathrm{C}$ in an Incubator for $60 \mathrm{~min}$. The slides were then taken directly from the incubator and deparaffinized in three changes of xylene for $5 \mathrm{~min}$ each, followed by three rinses in absolute ethanol (ETOH) for $2 \mathrm{~min}$ each. To eliminate staining due to endogenousperoxidase, sections were treated with an ETOH / $\mathrm{H}_{2} \mathrm{O}_{2}(45 \mathrm{ml}$ $\mathrm{ETOH} / 3 \mathrm{ml} \mathrm{H}_{2} \mathrm{O}_{2}$ ) block for $10 \mathrm{~min}$ at $42^{\circ} \mathrm{C}$. Slides were hydrated in decreasing concentrations of ethanol and rinsed in PBS. From this point in the assay, all antibody and complex incubations were carried out in a humidity chamber at $42^{\circ} \mathrm{C}$. Slides were pre-incubated for $10 \mathrm{~min}$ in $5 \%$ NHS diluted in PBS/2\% BSA, followed by incubation for $45 \mathrm{~min}$ with primary antibody. Slides were then rinsed in PBS and subsequently incubated in the presence of the secondary antibody for $20 \mathrm{~min}$ (Vector). Slides were rinsed in PBS, followed by a 20-min incubation in premixed Elite Universal Kit reagents as recommended by the product insert (Vector). The PBS rinse was repeated and sections were developed in the enzyme substrate DAB solution.

P53 immunoreactivity was recorded according to their intensity in Browne colure. Using light microscopy, certain cells exhibited noticeably stronger immunoreactivity than the rest. These cells were classified as strongly stained.

\section{Statistical analysis}

Data were analyzed by Student's $t$ test. Values are expressed as mean $\pm \mathrm{SE}$.

\section{Results}

\section{Effect of $\mathrm{NaSeO} 3$ in the prevention of lipid peroxidation}

MDA is an aldehyde end product of poly unsaturated fatty acids and related esters that it used to assess lipid peroxidation. $\mathrm{NaSeO} 3$ administration recorded NS change in liver and intestine tissues in comparison to control tissues. From table (1) whole body exposure of experimental animals to 5Gy . -radiation predicted a highly significant increase in lipid peroxidation $(\mathrm{p}<0.001)$ as compared to control group. Treatment of the experimental animals by $\mathrm{NaSeO} 3$ followed by whole body exposure to $5 \mathrm{~Gy}$. -radiation induced amelioration in lipid peroxidation compared to the irradiated group.

\section{Effect of $\mathrm{NaSeO3}$ on the GSH levels activity.}

Table (2) shows the effect of $\mathrm{NaSeO} 3$ on the level of GSH activity of liver and intestine tissues. Treatment of the experimental animals with $\mathrm{NaSeO} 3$ only influences a significant change as compared to control level. Exposure of the experimental animals to 5Gy of . -radiation, a significant decrease in reduced glutathione was noticed either in liver or intestine tissues reaching to $29.80 \%$ and $-34.21 \%$ respectively. Non significant change was observed in $\mathrm{NaSeO} 3$ irradiated group (5Gy) as compared to control group and significant increase was detected in comparison to control group. 


\section{Hanafi N.}

\section{Histopathological observations.}

\section{Liver}

The results of the microscopic investigation showed that liver of mice treated with 5 Gy $\gamma$-radiations (Fig1C) displayed erosion of the endothelial cell of the central vein $(\uparrow)$ and fragmentation of the hepatic cells $(\uparrow)$. In addition many of the hepatocytes manifested pyknotic nuclei. Liver tissue in mice treated with $\mathrm{NaSeO} 3$ recorded some hepatic cells atrophy in addition to the presence of some pyknotic nuclei (Fig 1B) and cell vaculation due to either $\mathrm{NaSeO} 3$ or $\mathrm{NaSeO} 3 \& 5$ of $\gamma$ radiation exposure (Fig $1 \mathrm{~B} \& \mathrm{D})$.

\section{Intestine}

In Fig (2) the histopathological observations in intestine tissue of mice exposed to 5 Gy $\gamma$-radiations was evaluated (G). Compact and shortening of intestinal villi (High magnification) were observed and decrease in goblet cells was detected. Treatment of experimental animals with $\mathrm{NaSeO} 3$ (F) showed normal appearance of intestinal tissue as compared to control tissue. Treatment of the experimental animals with $\mathrm{NaSeO} 3$ followed by $5 \mathrm{~Gy} \gamma-$ radiation $(\mathrm{H})$, some normalization in intestinal tissues was appeared.

\section{Immunohistochemical detection of $p 53$.}

Liver

Fig (3) illustrates the immunoreactivity of p53 in liver tissue. Control normal one (A) did not detect any immunoreactivity of $p 53$ expression. Exposure of experimental anim-als to 5Gy of $\gamma$-radiation (B), expression of p53 was observed in many of the hepatocytes $(\uparrow)$ which suffered from cytoplasmic vacuolation. Treatment of mice with $\mathrm{NaSeO} 3$ (C) revealed marked expression of $p 53$ in many of the hepatocyes compared to other treatment and more pronounced when liver tissue treated with $\mathrm{NaSeO} 3$ and exposed to 5 Gy $\gamma$-radiation (D).

\section{Intestine}

The intestinal p53 expression effected by different treatments was recorded in fig (4). Control intestine express p53 only in the muscularis externa region. Exposure to 5 Gy revealed highly p53-positive cells which mainly towards the base of the small intestinal crypts (F). Treatment of the experimental animals with $\mathrm{NaSeO} 3$ revealed a negative expression in intestinal $p 53$ (G). Mild p53 expression was recorded in some intestinal villi cells when the experimental animals were treated with $\mathrm{NaSeO} 3$ and exposed to $5 \mathrm{~Gy} \gamma$-radiation $(\mathrm{H})$.

Table (1): Effect of $\mathrm{NaSeO3}$ on MDA levels of mice exposed to $\gamma$-radiation.

\begin{tabular}{||l|c|l|l|c||}
\hline \multirow{2}{*}{ Organs } & \multicolumn{4}{|c|}{ Groups } \\
\cline { 2 - 5 } & Control & NaSeO3 & Radiation & NaSeO3+Radiation \\
\hline Liver & $104.14 \pm 0.42$ & $103.62 \pm 0.42^{\mathrm{NS}}$ & $184.82 \pm 0.57^{* * * *}$ & $143.46 \pm 1.38^{* * * *}$ \\
$\%$ of change & $100 \%$ & $-1.41 \%$ & $77.47 \%$ & $37.76 \%$ \\
\hline Intestine & $94.40 \pm 0.35$ & $93.47 \pm 0.26^{\mathrm{NS}}$ & $121.62 \pm 0.69^{* * *}$ & $106.09 \pm 0.40^{* * *}$ \\
$\%$ of change & $100 \%$ & $-0.99 \%$ & $28.83 \%$ & $12.38 \%$ \\
& & & & \\
\hline
\end{tabular}

***Significantly different at $\mathrm{P}<0.001$

**significantly different at $\mathrm{P}<0.01$

Values are the mean of 5 observations \pm S.E 
Table (2): Effect of $\mathrm{NaSeO3}$ on GSH levels activity of mice exposed to $\gamma$-radiation.

\begin{tabular}{||l|c|c|c|c||}
\hline \multirow{2}{*}{ Organs } & \multicolumn{4}{|c||}{ Groups } \\
\cline { 2 - 5 } & Control & NaSeO3 & Radiation & NaSeO3+Radiation \\
\hline Liver & $104.47 \pm 0.38$ & $162.22 \pm 0.47^{* * *}$ & $73.34 \pm 0.19^{* * *}-$ & $101.45 \pm 2.57^{\mathrm{NS}}$ \\
\% of change & $100 \%$ & $55.28 \%$ & $29.80 \%$ & $-2.89 \%$ \\
\hline Intestine & $161.42 \pm 0.36$ & $218.22 \pm 0.40^{* * *}$ & $106.20 \pm 0.46^{* * *}-$ & $166.52 \pm 2.63^{\mathrm{NS}}$ \\
\% of change & $100 \%$ & $35.19 \%$ & $34.21 \%$ & $3.16 \%$ \\
\hline
\end{tabular}

Legends as in table (1)
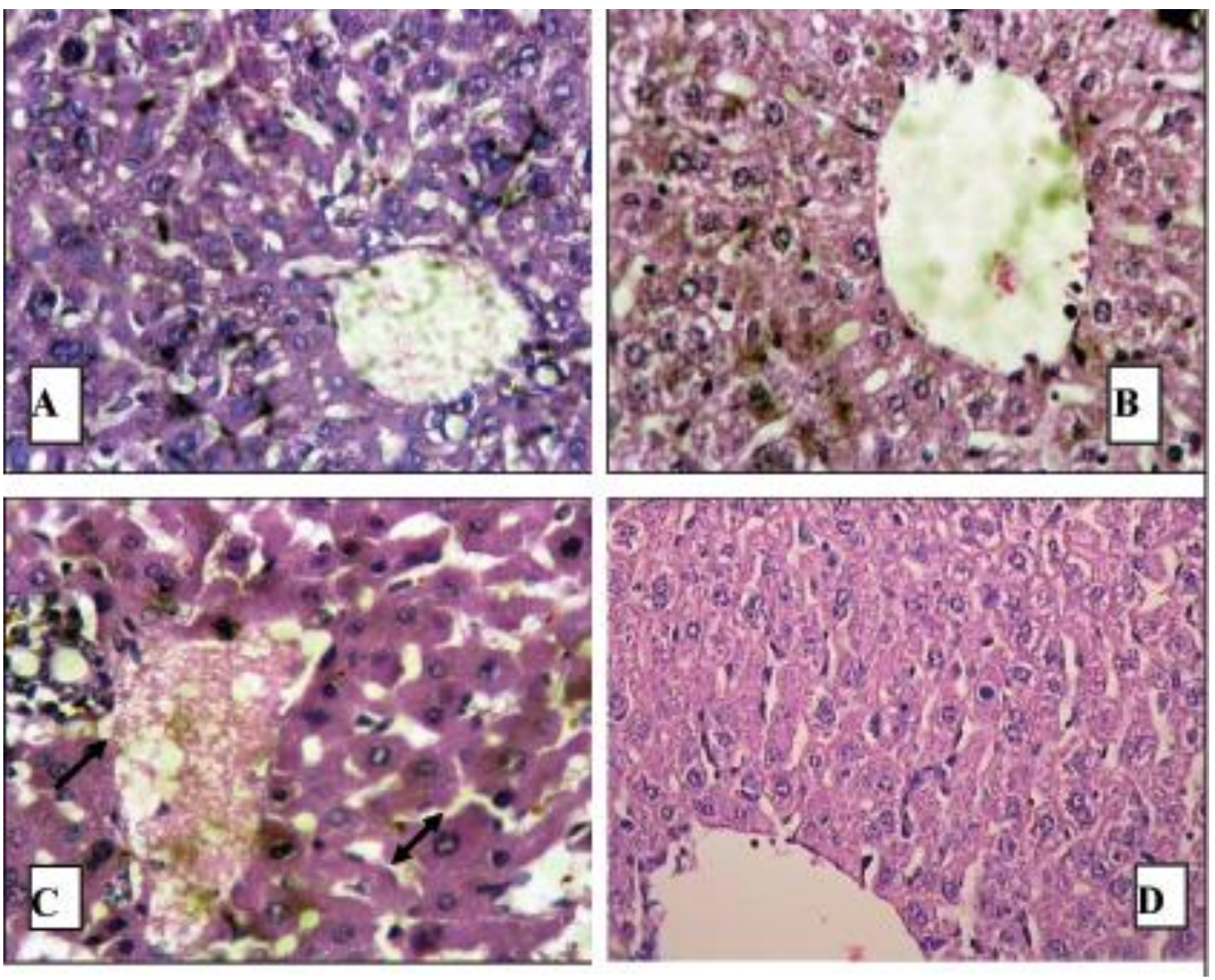

Fig (1): Liver sections of mice given $\mathrm{NaSeO} 3$ and subjected to $\gamma$-radiation. (H\&E stain $x$ 400). (A): Normal control liver tissue section. (B): Section in liver of mouse treated with NaSeO3. (C): Section in liver of mouse exposed to 5GY $\gamma$-radiation.(D): Section in liver of mouse treated with $\mathrm{NaSeO3}$ and exposed to $5 \mathrm{GY}$ of $\gamma$-radiation. 


\section{Hanafi N.}
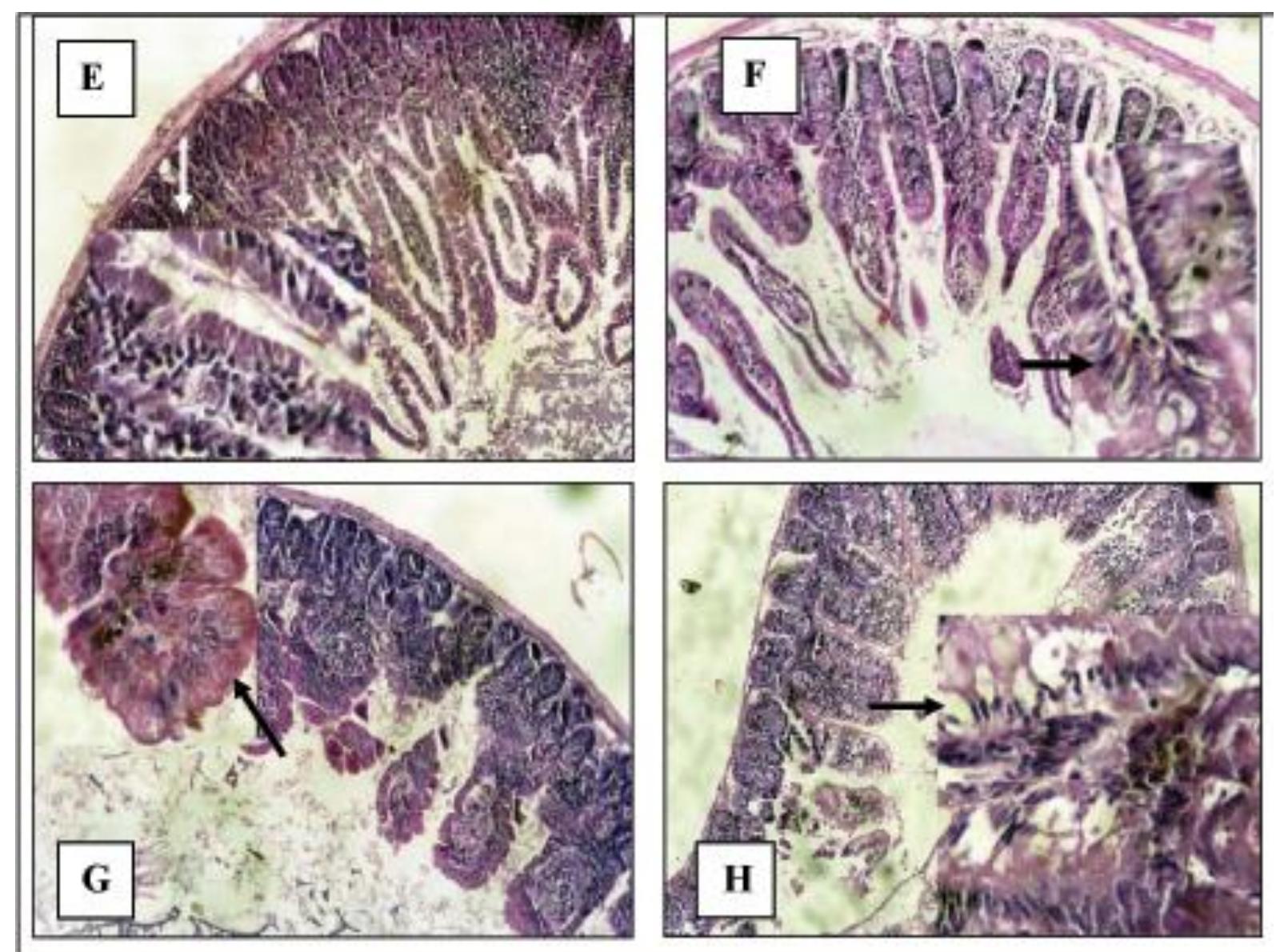

B A.Fig (2): Intestine sections of mice given NaSeO3 and subjected to $\gamma$-radiation. (H\&E stain $x$ 100) (Arrow pointed to high magnification). (E): Normal control intestine tissue section. (F): Section in intestine of mouse treated with NaSeO3. (G): Section in intestine of mouse exposed to 5GY $\gamma$-radiation. $(\mathrm{H})$ :Section in intestine of mouse treated with $\mathrm{NaSeO3}$ and exposed to $5 \mathrm{GY}$ $\gamma$-radiation. 

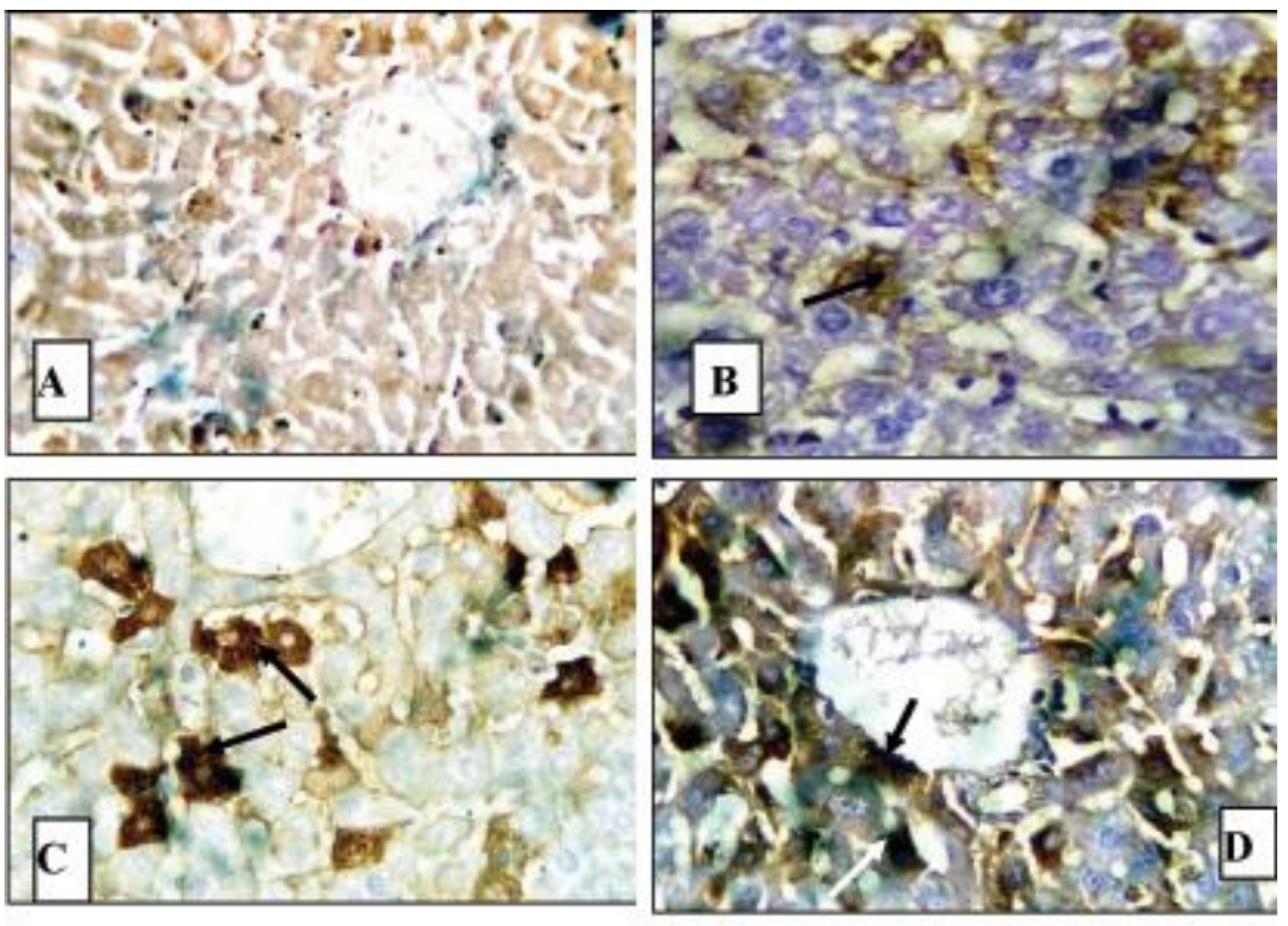

Fig (3): Staining of P53 expression in liver sections by using Ab-1 mouse monoclonal antibody for immunohistochemical detection of murine $p 53$ in formalin fixed paraffin sections. Magnification was $\mathrm{x} 400$ for all figures. (A): Represent negative p53 expression in control liver tissue section. (B): Expression of p53 in liver tissue in animals exposed to $5 \mathrm{~Gy} \gamma$-radiation. (C): Expression of p53 in liver tissue when control mouse treated with NaSeO3. (D): Represent the expression of $p 53$ when control mouse treated with $\mathrm{NaSeO3}$ and exposed to $5 \mathrm{~Gy} \gamma$-radiations. 


\section{Hanafi N.}
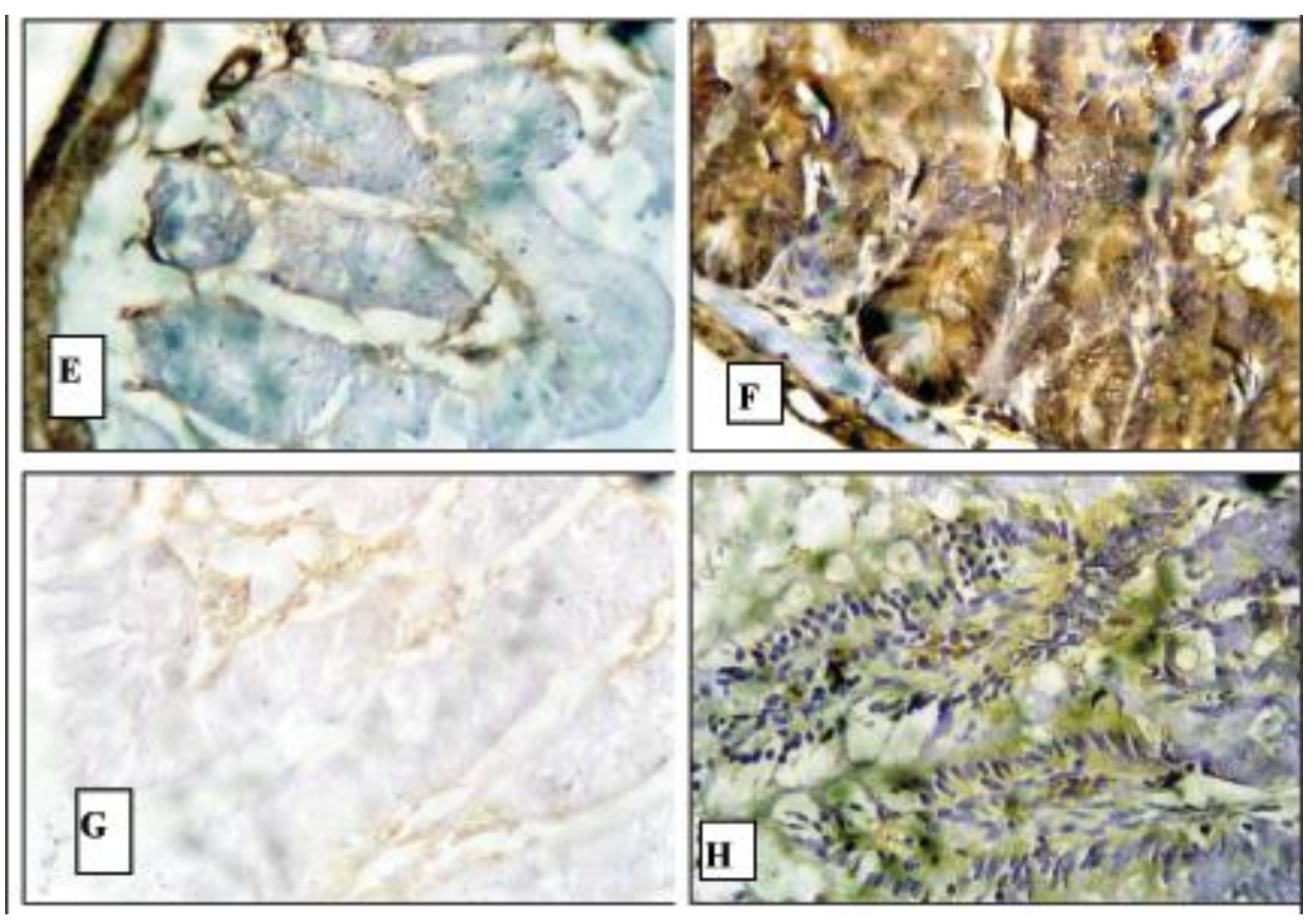

Fig (4): Staining of $p 53$ expression in intestine tissue sections by using Ab-1 mouse monoclonal antibody for immunohistochemical detection of murine $p 53$ in formalin fixed paraffin embedded intestine sections. Magnification was x400 for all figures. (E): Represent negative $p 53$ expression in control intestine tissue section. (F): Expression of p53 in intestine tissue as affected by $5 \mathrm{~Gy}$ of $\gamma$-radiation exposure. $(\mathrm{G})$ : Expression of $p 53$ in intestine tissue when control mouse treated with $\mathrm{NaSeO}$. $(\mathrm{H})$ : Represent the expression of p53 in intestine tissue when control mouse treated with $\mathrm{NaSeO} 3$ and exposed to 5 Gy of $\gamma$-radiation.

\section{Discussion}

It is known that the exposure to Radiation produces various reactive oxygen species (ROS) in biological systems (Adler et al., 1999) which react and damage cellular macromolecules (Sies, 1986).

In the current study a significant increase in lipid peroxiation was observed in liver and intestine tissues after whole body $\gamma$-irradiation due to oxidation of sulfhydryl group or due to the diminished activity of glutathione reductase (GR), ( Sarkar et al.,1998). Also, Erden and Kahraman (2000) recorded decline in GR in liver tissue of animals exposed to irradiation and contributed this decline to the inactivation of $\mathrm{SH}$ groups existing at the active site of the enzyme molecule by ${ }^{\cdot} \mathrm{OH}$ and $\cdot \mathrm{O}_{2}$ which are formed as result of irradiation. Additionally Irshad and Chaudhuri (2002) indicated that there is a close relaion between depletion of GSH and antioxidant enzymes and increase in lipid peroxidation which leads to increase in MDA and the damage in liver tissue which is based on the excessive formation of ROS as well as the depletion of cellular antioxidants which leads to histopathological observations. Atrophy in the endothelial cell of the central vein, the presence of fragmented hepatic cells and many of the hepatocytes have pyknotic nuclei (Li-Hua et al., 2006). In addition, the exposure of 
experimental animals to 5 Gy $\gamma$-radiation revealed compact and the shortening of intestinal villi and decrease in goblet cells. Jindal et al. (2006) observed that irradiation produced a significant decrease in crypt survival, mitotic figures and villus length; whereas goblet and apoptic cells showed a significant increase in irradiated animals. Becciolini et al. (1995) predicted that acute intestinal toxicity may occur in response to therapeutic or accidental exposure to ionizing radiation. At the histopathological level, it is characterized by a decrease in the depth of the intestinal crypts and the height of the villi. It is associated with basement membrane degradation, and ultimately leads to mucosal barrier breakdown and ulceration.

In the current study supplementations of selenium in the form of $\mathrm{NaSeO}_{3}$ revealed a non significant change in the MDA level in the liver and intestine tissues while a highly significant increase in GSH level was predicted because Selenium have its main role as an antioxidant in the enzyme selenium-glutathione-peroxidase production. This enzyme neutralizes hydrogen peroxide which is produced by some cell processes and would otherwise damage cell membranes (Roderick et al., 2002).

Shani et al. (2003) postulated that histological examination of liver tissue showed normal pattern due to the treatment of experimental animals with $\mathrm{NaSeO}_{3}$.

There is a great relation between the antioxidant status of the tissue cells and the p53 expression. Involvement of plasma membrane and reactive oxygen species (ROS) generated by genotoxic stress free radicals caused damage to cellular membrane which in turn damage to biomolecules such as proteins and lipids of membrane which shown to initiate cascade of biochemical reactions and signalling events resulting in loss of cellular functions and eventually cell death (Pandey and Mishra, 1999, 2000 and 2003). Accumulated evidences suggest the active involvement of ROS as signalling molecule for the initiation and execution of apoptotic death has been shown that decrease in pool of intracellular glutathione (GSH), by lowering the cytoplasmic reducing capacity and increasing the MDA level and which leads to the p53 expression resulting in apoptosis (Pandey and Mishra.,2003). On the other hand when tissue cells are exposed to ionizing radiation, they initiate a complex response that includes the arrest of cell cycle progression in G1 and G2, apoptosis and DNA repair. DNA is an important subcellular target of ionizing radiation, but oxidative damage to plasma membrane lipids initiates signal transduction pathways that activate apoptosis and that may play a role in cell cycle regulation. How is DNA damage converted into intracellular signals for cell cycle arrest? The ataxia telangectasia mutant (ATM) protein and/or the DNA-dependent protein kinase (DNAPK), that are both activated by DNA damage, may initiate cell cycle arrest by activating the $p 53$ tumor suppressor protein. The $p 53$ protein acts as a transcription factor and regulates expression of several components implicated in pathways that regulate cell cycle progression (Teyssier et al., 1999).

In the current study exposure of experimental animals to 5Gy $\gamma$-radiation, expression of highly p53-positive cells in the small intestinal crypts and in many of the hepatocytes which suffered from cytoplasmic vacuolation were observed.

James et al. (1998) expressed that exposure to $\gamma$-radiation resulting strong $p 53$ expression and a higher frequency of apoptosis relative to the cells towards the top of the intestinal crypts and postulated that in apoptosis and a reduction in the fraction of proliferating cells; these cellular responses were associated with a time and dose-dependent increase in the expression of $p 53$.

However the finding of Carol et al., (1995) reported that p53 protein accumulation was not detected in the hepatocytes of the irradiated mouse while the intestine tissue predict p53 protein expression.

Treatment of mice with $\mathrm{NaSeO} 3$ revealed marked expression of $p 53$ in many of the hepatocyes as compared to other treatment for the role efficient apoptotic process of $\mathrm{NaSeO}_{3}$ in normal tissues to prevent malignant transformation and help to correct age-related tissue damage (Zhang and Herman 2002). Also Shen et al., (2000) 


\section{Hanafi N.}

found that Se-induced oxidative stress and apoptosis are closely related to the intracellular level of GSH but the treatment of the experimental animals with $\mathrm{NaSeO}_{3}$ revealed a negative expression of intestinal $p 53$.

Pronounced expression of p53 was noticed in liver and intestine tissues when the experimental animals treated with $\mathrm{NaSeO}_{3}$ and exposed to 5 Gy $\gamma$-radiation.

The accumulation of $p 53$ protein in response to genotoxic stress like radiation exposure appears to be a means of inducing growth arrest and apoptotic cell death by the transcriptional regulation of other genes (Kern et al., 1991; Kastan et al., 1992; ElDeiry et al., 1993), and possibly by other direct mechanisms (Caelles et al., 1994) and the p53 expression after genotoxic (Merritt et al., 1994 and Clarke et al., 1994). It is known that $\mathrm{NaSeO} 3$ was the main part of the tissue providing with selenium. Selenium activates certain proapoptotic genes linked to $p 53, \mathrm{NF} \kappa \mathrm{B}$ and stress signal pathways in response to "danger signals" in mic liver (Huawei et al., 2003). Since Selenium was the main one for its role as an antioxidant in the enzyme selenium-glutathione-peroxidase, which neutralizes hydrogen peroxide produced by some cell processes and would otherwise damage cell membranes. Selenium prevented radiation induced apoptosis, but did not decrease the levels of radiation induced $p 53$; however selenium prevents radiation induced cell death by inhibiting p53-independent cell death pathways (Rafferty et al., 2003).

It is possible to conclude that $\mathrm{NaSeO} 3$ supplementation to mice exposed to ionizing radiation could ameliorate effects against cellular damage caused by radiation oxidative stress.

\section{References}

1. Adler V, Yin Z, Tew KD and Ronai, Z, (1999): Role of redox potential and reactive oxygen species in stress signalling. Oncogene, 18: 104-111.

2. Becciolini A, Balzi $M$ and Potten CS (1995): Radiation effects on proliferation and differentiation in the rat small intestine In. Potten CS, Hendry JH, eds. Radiation and Gut. Amsterdam: Elsevier pp 85-143
3. Caelles C, Helmberg A and Karin M (1994): p53-dependent apoptosis in the absence of transcriptional activation of $p 53$ target genes. Nature, 370: 220-224

4. Carol A, Midgley BO, Cecilie VB, David BT, David PL and Peter AH (1995):

Coupling between gamma irradiation, p53 induction and the apoptoti response depends upon cell type in vivo. Cell Sci.,108: 1843-1848.

5. Clarke AR, Gledhill S, Hooper ML, Bird CC and Wyllie AH (1994): p53 dependence of early apoptotic and proliferative responses within the mouse small intestinal epithelium following $\mathrm{g}$ irradiation. Oncogene, 9: 1767-1773.

6. El-Deiry WS, Tokino T, Velculescu VE, Levy DB, Parsons R, Trent JM, Lin D, Mercer WE, Kinzler KW and Vogelstein B (1993): WAF1, a potential mediator of p53 tumor suppression. Cell, 75: 817-825.

7. Erden IM and Kahraman A (2000): The protective effect of flavonol quercetin gainst ultraviolet a induced oxidative stress in rats. Toxicology, 23: 21-29.

8. Friedberg EC (2003): DNA damage and repair. Nature, 421: 436-440

9. Ganther HE (1999): Selenium metabolism, selenoproteins and mechanisms of cancer prevention: complexities with thioredoxin reductase.Carcinogenesis, 20: 1657-1666.

10. Hall PA, McKee PH, Menage Hd, Dover $R$ and Lane DP (1993): High levels of p53 protein in UV irradiated human skin. Oncogene, 8: 203- 208

11. Hall PA (1994): The role of $p 53$ in spontaneous and radiation-induced apoptosis in the gastrintestinal tract of normal and p53 deficient mice. Cancer Res.,54: 614-617.

12. Holben D H and Smith AM (1999): The diverse role of selenium within selenoproteins: a review. J. Am. Diet Assoc., 99: 836-843.

13. Huawei Z, Cindy D D. and John W F. (2003): Effect of selenium-enriched broccoli diet on differential gene expression in min mouse liver. Nutritional Biochemistry, 14(4): 227-231.

14. Ip C. (1998): Lessons from basic research in selenium and cancer prevention. J. Nutr. 128: $1845-1854$.

15. Irshad $M$ and Chaudhuri PS (2002): Oxidant-antioxidant system: role and significance in human body. Indian J. Exp. Biol., 40(11):1233-1239.

16. James WW, Mark DP, John AH, and Christopher SP (1998): Radiation-Induced $p 53$ and $p 21 \mathrm{WAF}-1 / \mathrm{CIP} 1$ expression in the 
murine intestinal epithelium. poptosis and Cell Cycle Arrest. Am. J. of Pathol., 153, No. 3.

17. Jindal A, Soyal D, Singh I and Goyal PK (2006): Modifications of radiation-induced damage in mice by rosemarinus officinalis extract (ROE) Pharmacologyonline,2: 6375.

18. Kastan MB, Zhan Q, el, DW, Carrier F, Jacks T, Walsh WV, Plunkett BS, Vogelstein, B and Fornace A J (1992): A mammalian cell cycle checkpoint pathway utilizing p53 and GADD45 is defective in ataxia-telangiectasia. Cell, 71: 587-597.

19. Kern SE, Kinzler KW, Bruskin, A., Jarosz, D., Friedman, P., Proves, C. and 20. Vogelstein, B. (1991): Identification of p53 as a sequence-specific DNA-binding protein. Science, 252: 1708-1711.

20. Kuchan MJ and Milner JA (1992): Influence of intracellular glutathione on selenite-mediated growth inhibition of canine mammary tumor cells. Cancer Res., 52: 1091-1095.

21. Lanfrancone L, Pelicci G and Pelicci PG( 1994): Cancer genetics. Curr. Opin. Genet. Dev., 4:109 - 119.

22. Li-Hua S, Hong-Li Y and Dong- Lian C (2006): Protective effect of soybean isoflavone against gamma irradiation induced damage in mouse. J.Radiat. Res., 47: 157-165.

23. Merritt AJ, Potten CS, Kemp CJ, Hickman JA, Balmain A, Lane DP and Hall PA (1994): The role of p53 in spontaneous and radiation-induced poptosis in the gastrintestinal tract of normal and p53 deficient mice. Cancer Res., 54: 614617.

24. Moron MS, Depierre JW and Mannervik B (1979): Levels of GSH, GR and GST activities in rat lung and liver. Biochem. Biophys., 582:67-78.

25. Ohkhawa $H$, Ohishi $N$ and Yogi $K$ (1979): Assay for lipid peroxidation in animals tissue by thiobarbituric acid reaction. Anal. Biochem. , 95:351-358.

26. Okusa $Y$, Ichikura $T$ and Tamakuma S (1996): Immunohistochemical staining for the p53 protein and proliferating cell nuclear antigen in familial clustering of gastric cancer.J.Surg.Oncol.,62:253-257.

27. Pandey BN and Mishra KP (1999): Radiation induced oxidative damage modification by cholesterol in liposomal membrane. Radiat. Phys. Chem., 54: 481-489.

28. Pandey BN and Mishra KP (2003): In vitro studies on radiation induced membrane oxidative damage in apoptotic death of mouse thymocytes. Intl. J. Low Radiat., 1:113-119.

29. Rafferty TS, Beckett GJ, Walker C, Bisset YC and McKenzie RC(2003): Selenium protects primary human keratinocytes from apoptosis induced by exposure to ultraviolet radiation. Clin. Exp. Dermatol.,28 (3):294-300.

30. Roderick CM, John $R A$ and Geoffrey JB (2002): Selenium and the Regulation of Cell Signaling, Growth, and Survival: Molecular and Mechanistic Aspects Apr. 4(2) : 339-351.

31. Roviello F, Marrelli D, Vindigni C, De Stefano A, Spina D and Pinto E (1999): $P 53$ accumulation is a prognostic factor in intestinal-type gastric carcinoma but not in the diffuse type. Ann. Surg. Oncol., 6: 739 -745 .

32. Ryan KM, Phillips AC and Vousden KH (2001): Regulation and function of the p53 tumor suppressor protein. Curr, Opin, Cell Biol., 13: 332 - 337.

33. Sarkar S, Yadav $P$ and Bhatnagar $D$ (1998): Lipid peroxidative damage on cadmium exposure and alterations in antioxidant system in rat erythrocytes: a study with relation to time. J. Biometals., 11(2): 153-157.

34. Shani S, Anna A, Rita $K$ and Oren T (2003): Selenite sensitizes mitochondrial permeability transition pore opening in vitro and in vivo: a possible mechanism for chemo-protection. Biochem. J., 370: 283-290.

35. Shen H, Yang C, Liu J and Ong C (2000): Dual role of glutathione in seleniteinduced oxidative stress and apoptosis in human hepatoma cells. Free Radic. Biol. Med., 28(7):1115-24.

36. Sies H (1986): Biochemistry of oxidant stress. Angew. Chem. Int. Ed. Engl., 25:1058-1071.

37. Starzynska T, Bromley M, Ghosh A and Stern PL (1992): Prognostic significanse of $p 53$ overexpression in gastric and colorectal carcinomas. Br. J. Cancer, 66: $558-562$.

38. Teyssier F, Bay JO, Dionet $\mathrm{C}$ and Verrelle $P$ (1999) : Cell cycle regulation after exposure to ionizing radiation. Bull Cancer, 86(4):345-57.

39. Zhang $Y$ and Herman B (2002): Ageing and apoptosis. Mech. Ageing Dev. 123: 245-260

40. Zhou BB and Elledge SJ (2000): The DNA damage response: putting checkpoints in perspective. Nature, 408: 433-439. 
دور سالينات الصوديم فى تخفيف الإجهاد التأكسدى الناتج عن التعرض لأشعة جاما

\section{نعمات حنفى أحمد}

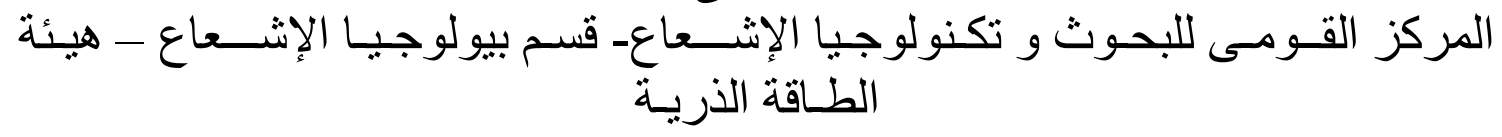

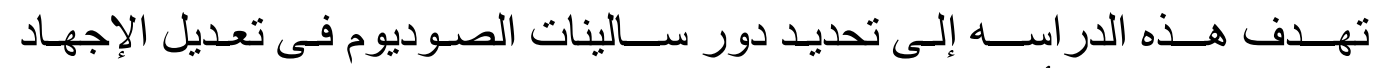

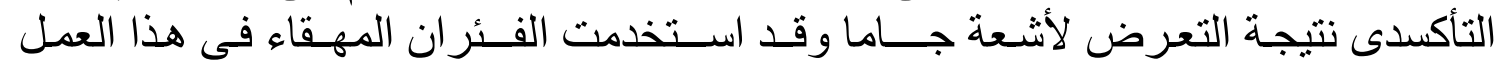

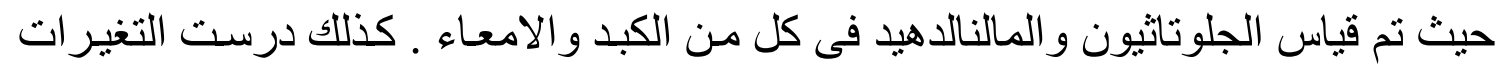

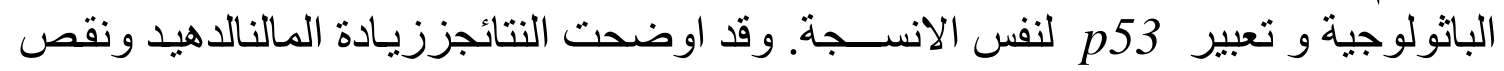

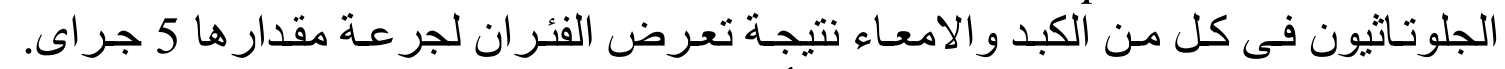

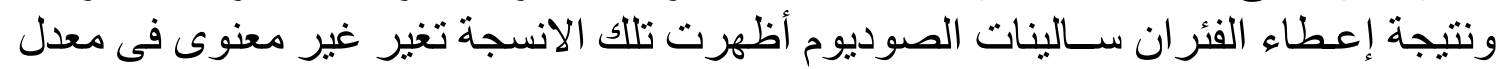

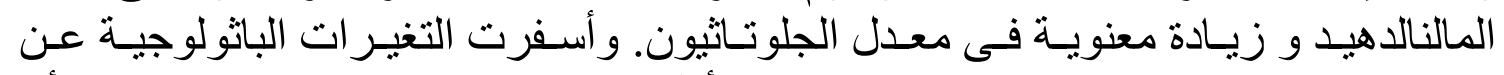

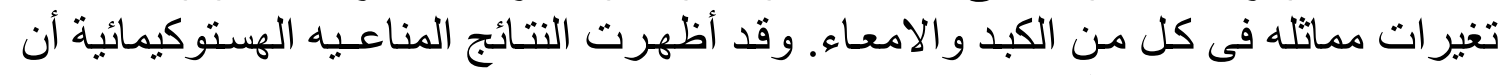

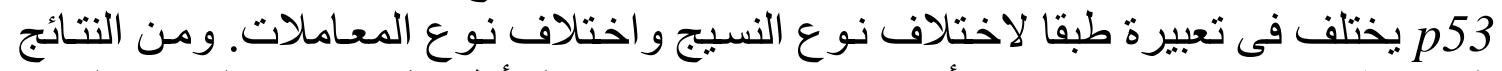

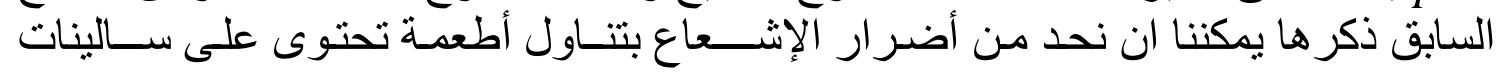
الصوديوم. 